\title{
MACRO AND MICROMORPHOLOGY OF SCHINUS TEREBINTHIFOLIUS RADD. GROWING IN EGYPT PART 1: LEAVES AND STEMS
}

Mohamed S. Karawya ${ }^{1}$, Mohamed S. Afifi ${ }^{2 *}$, Ahmed F. Halim ${ }^{2}$ and Saleh H. El-Sharkawy ${ }^{2}$

\author{
${ }^{1}$ Department of Pharmacognosy, Faculty of Pharmacy, Cairo \\ University, Egypt \\ ${ }^{2}$ Department of Pharmacognosy, Faculty of Pharmacy, Mansoura \\ University, Egypt
}

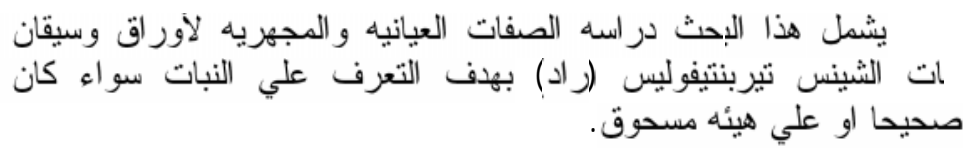

The macro- and microscopical characters of the leaves and stems of Schinus terebinthefolius Radd. (Family: Anacardiaceae) are presented.

\section{INTRODUCTION}

Among the tannin containing plants are Schinus terebinthifolius Radd., S. molle and S. dependens Ort. (Family: Anacardiaceae) which grow well in Egypt. It was reported ${ }^{1-3}$ that plants of the Family: Anacardiaceae have both medicinal and economic values. The volatile oil, particularly of the fruits and leaves is used in the treatment of gonorrhea. ${ }^{4}$ Their liquid extracts are used for the treatment of amenorrhea and dysmenorrheal. ${ }^{5}$ The ethanolic extract of Schinus terebinthifolius Radd. was found to show an anti-bacterial activity against Staphylococcus aureus. ${ }^{6}$ Polyphenols isolated from Schinus terebinthifolius Radd. have shown an anti proliierative and anti-tumor effects. ${ }^{7}$

The chemical investigation of Schinus terebinthifolius Radd., was carried out and showed the possibility of its use in tanning leather ${ }^{8 \& 9}$ and as emulsifier in manufacture of Halawa tehiniya $^{10}$ due to its tannin and saponin contents respectively. Pentagalloyl glucose isolated from Schinus terebinthifolius Radd. showed a xanthine oxidase inhibirtory effect and inhibit the formation of

Received in 19/7/2006 \& Accepted in 12/11/2006

${ }^{*}$ Corresponding author. 
uric acid and used in treatment of gout. ${ }^{10}$ Some morphological characters of Schinus terebinthifolius Radd., were briefly described by Baily, ${ }_{11}$ Hill, ${ }^{12}$ Benson, ${ }^{13}$ Subhush, ${ }^{14}$ Trivedio, ${ }^{15}$ Rendle ${ }^{16}$ and Purseglov. ${ }^{17}$

Reviewing the current literature, little was found concerning the botanical study of the plants belonging to the family: Anacardiaceae. ${ }^{10 \& 18}$ So, it was found of interest to carry out such study.

\section{MATERIAL}

The leaves and stems of Schinus terebinthifolius Radd., were collected from perennial plants growing near Mansoura at October to February. The plant was identified by Prof. Dr. Nabil El-Hadidi (Prof. of Systematic Botany, Faculty of Science, Cairo Univ.). The collected materials were preserved in alcohol containing 5\% glycerol.

Abreviations: D, diameter; L, length; $\mathrm{H}$, height; $\mathrm{W}$, width.

\section{MACROMORPHOLOGY}

Schinus terebinthifolius Radd: It is an evergreen tree of about 2 to 5 meter in length and 10 to $40 \mathrm{~cm}$ in diameter. The plant has an erect, solid, cylindrical, monopodially branched stem carrying alternate cauline leaves. The stem has swollen nodes and short solid internodes. The young stem is green with purplish batches near the nodes. The old stem is pale brown in colour and hard to break showing longitudinal striations and few scattered lenticels. The fracture is fibrous exposing yellowish white interior. The plant flowers after three years of cultivation, at the beginning of September to the end of October. The flowers are small, yellowish white in colour grouped in axillary or terminal panicles. The fruits are red coloured and appear from the begining of November to the end of December.

The leaf: The leaves (Fig. 1A) are alternate, compound of imparipinnate type, consisting of 5 to 9 sessile and nearly glabrous or slightly hairy leaflets, with green to purplish cylindrical rachis. It measures about 12 to $18 \mathrm{~cm}$ in length, the basal leaflets are sessile oblong to oblong lanceolate in shape, measuring 6.7 to $10 \mathrm{~cm}$ in length and 1.5 to $3.2 \mathrm{~cm}$ in width with assymmetric base. The terminal leaflets are similar to the side leaflets except that they are petiolate with symmetric base. The lamina has an acute apex with an entire sometimes minutely serrate or notched margin. Most leaflets are entire towards the base. Both surfaces are smooth, the upper being dark and the lower light green. The vennation is reticulate pinnate, the lateral veins anastimose near the margin of the leaflets to from an irregular line more or less parallel to the margin. The midrib is prominent on both surfaces but more distinct on the lower one. The leaflets have coriaceous occasionally papery texture. They have a characteristic aromatic odour, resembling that of black pepper and aromatic astringent bitter taste. 

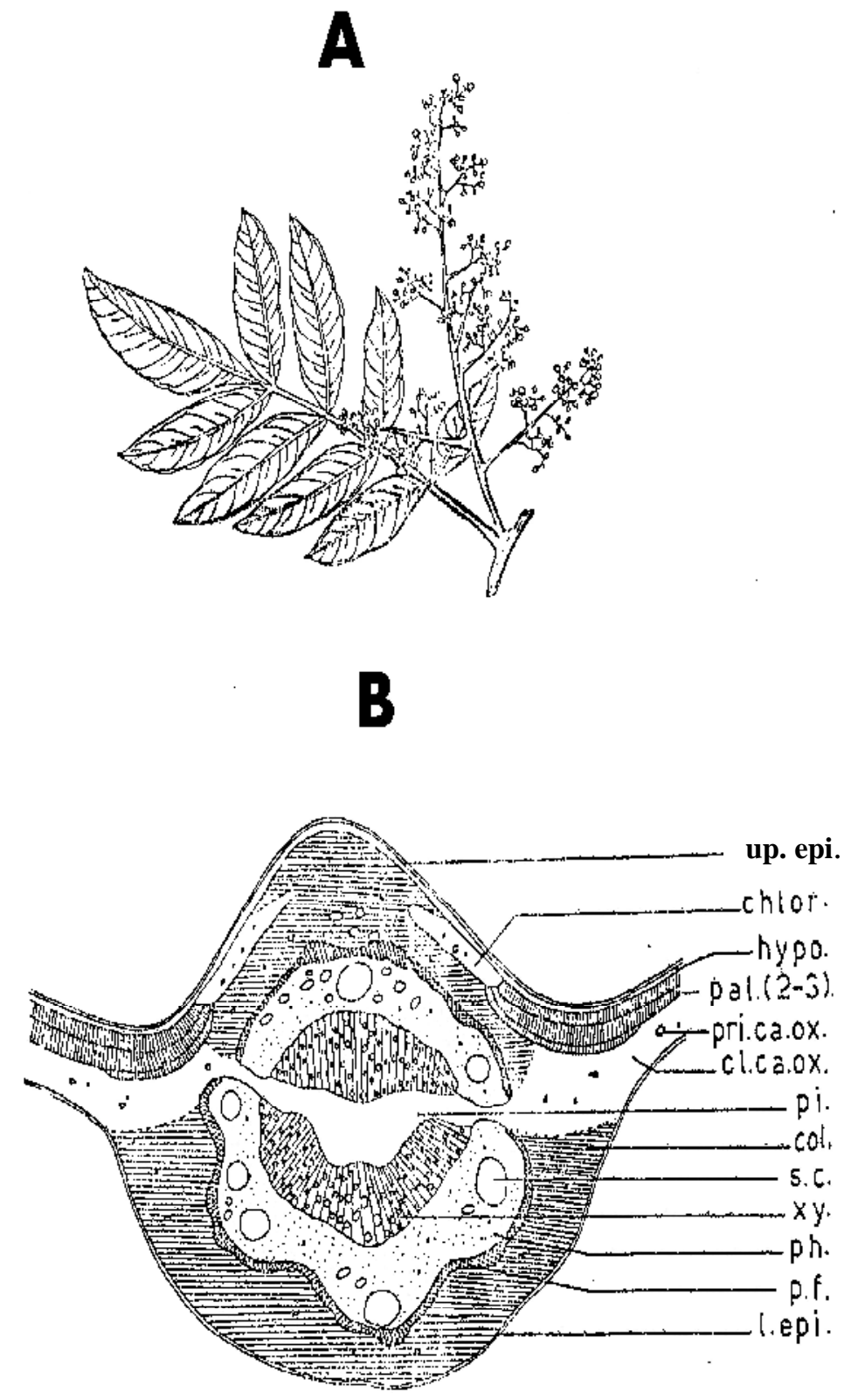

Fig. 1: The leaf

A- Entire with flowering branch

$(\mathrm{X} 0.7)$

B- Diagramatic transverse section of leaflet

(X 77)

Chl., chlorenchyma; cl. ca. ox., cluster of calcium oxalate; col. collenchyma; hypo., hypodermis; 1. ep., lower epidermis ; pal., palisade; p.f., pericyclic fibre ; ph., phloem; pi., pith; pri. ca. ox., prism of calcium oxalate; s.c., secretory canal; up. epi., upper epidermis; xy., xylem. 
The stem: It is solid nearly cylindrical, monopodially branched, reaching up to 5 meters in length and $40 \mathrm{~cm}$ in diameter. It is purplish green in colour, showing longitudinal striations and few scattered lenticels (in old one) and has a short fibrous fracture. It possesses a characteristic aromatic black pepper like odour and aromatic slightly bitter astringent taste.

\section{MICROMORPHOLOGY}

The Leaflet (Fig. 1B): A transverse section in the lamina of the leaflet is biconvex in the midrib region, being more prominent on the lower surface. The leaflet is dorsiventral, showing 23 layers of palisade which are interrupted in the midrib region by several rows of collenchymatous cells. The palisade is separated from the epidermis by one layer of parenchymatous hypodermis. The cortical tissue is traversed by a vascular strand showing secretory canals in phloem region. The pith is narrow (1/6 the whole tissue) and central.

The upper epidermis (Fig. 2B): It is formed of tabular, polygonal to subrectangular or elongated cells on neural part, with thin straight or slightly curved anticlinal walls and slightly convex outer tangential walls, covered by distinctly striated thick cuticle. They measure L. 11-31-44 $\mu$, W. 8-20-30 $\mu$ and H. 8-14-20 $\mu$. For neural part, they measure L. 33-57-70 $\mu$, W. 15-20-35 $\mu$ and H. 10-12-14 $\mu$.
The lower epidermis (Fig. 2C) is similar to the upper, but the cells are smaller and measure L. 10-19-30 $\mu$, W. 5-11-20 $\mu$ and H. 6-10-12 $\mu$.

The stomata: They are occasionally present, especially on the lower surface, being few on the upper surface. They are almost oval or occasionally rounded in outline sunken and of anomocytic type, being surrounded by 4 to 7 cells. They measure L. 11-29-40 $\mu$ and W. 10-12$18 \mu$. The stomatal index of the upper surface ranges from 1.51 to 2.32 and for the lower surface 10.20 to 13.77 .

Occasional non-glandular hairs: They are present on the upper surface and more frequent on the lower, especially on the midrib and big veins. They are of two types, conical unicellular as well as uniseriate multicellular of 3 to 5 cells with blunt apex. Both are covered by warty cuticle. The unicellular hairs measure L. 17-30-115 $\mu$ and W. 5-9-11 $\mu$, while the multicelluiar ones measure L. 25-45-200 $\mu$ and W. 6-10-12 $\mu$.

The hypodermis (Fig. 2A\&E): It is formed of one layer of pitted parenchymatous cells, measuring $\mathrm{L}$. 12-35-45 $\mu$, W. 10-20-27 $\mu$ and H. 9$16-21 \mu$

The mesophyll: It is differentiated into upper palisade and spongy mesophyll. The palisade is formed of 2 to 3 layers of cylindrical, columnar thin walled cells. Occasional clusters of calcium oxalate crystals measuring D. 


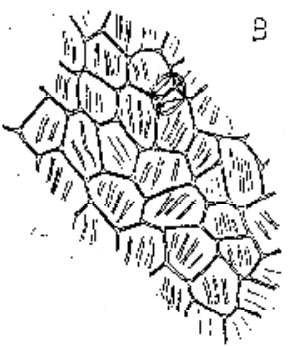

A

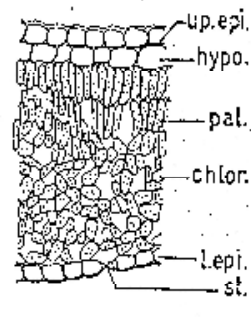

L.ep

ro

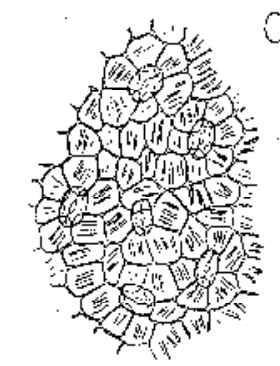

l.epì.

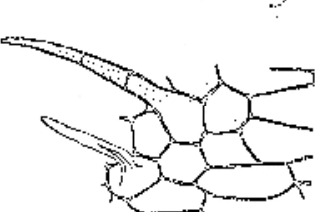

ri.epi

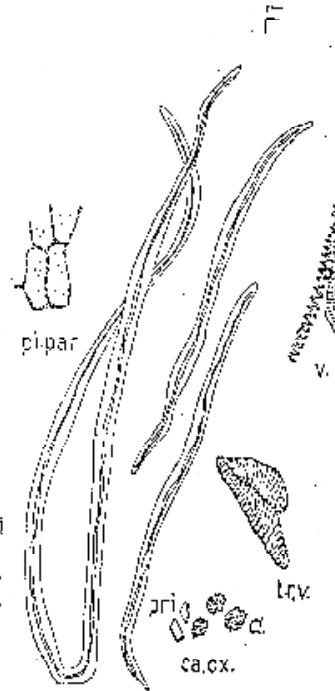

(1)

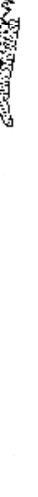

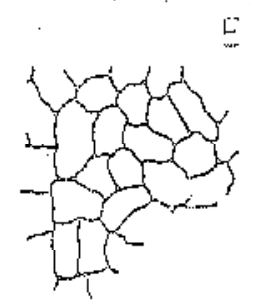

r.jpo. c.f.

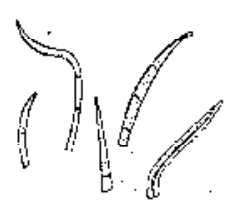

ti:

Fig. 2: The leaflet

A- Detailed transverse section of lamina

(X 230)

B- Upper epidermis

(X 300)

C- Lower epidermis

(X 300)

D- Neural surface

(X 300)

E-Hypodermis

(X 250)

F-Powder (Leaf)

(X 105)

chl., chlorenchyma; cl. ca. ox., cluster of calcium oxalate; hypo., hypodermis ; 1. ep., lower epidermis; n. ep., neural epidermis; pal., palisade; p.f., pericyclic fibre; pi.par., pith parenchyma of hypodermis; st., stomata; tr. v., tracheidal vessel; tri., trichome; up. ep., upper epidermis; v., vessel. 
3-10-15 $\mu$, are scattered throughout the palisade layer particularly that abutting upon the hypodermis (the palisade ratio is 11.1-16.3).

The spongy tissue: It consists of irregular or round chlorenchymatous cells with large intercellular spaces and measure D. 10-12-16 $\mu$. It is traversed by few secratory canals measuring D. 20-25-50 $\mu$ and show scattered cluster crystals of calcium oxalate.

The cortical tissue (Fig. 3): The cortical tissue in the neural region below the upper epidermis consists of one layer of thick pitted parenchymatous hypodermis which may contain cluster crystals of calcium oxalate, msimilar to those present in the spongy tissue. Below the hypodermis is a layer of collenchyma, measuring D. 18-20-23 $\mu$. Nonlignified pericyclic fibers are found either solitary or in groups of arc-shaped strands. They are thick walled with narrow lumen and blunt apex measure L. 400-1100-1500 $\mu$ and D. 5-7-10 $\mu$. The vein islet number range from 1.3 to 3.9 and the veinlet termmation number varies from 8.2 to 12.1 .

The vascular tissue (Fig. 3): It is formed of 2 to 12 vascular bundles forming a ring inturrupted by narrow bands of parenchyma. The phloem is directed towards the outside and the xylem to inside enclosing a central narrow pith. The xylem consists of 3 to 5 radial rows of vessels separated from each other by unsieriate or biseriate medullary rays, tracheids and wood parenchyma. The vessels are lignified, spiral, annular and reticulate, measuring D. 12-16-31 $\mu$. The tracheids are elongated, reticulate and lignified, measuring L. 50-80-150 $\mu$ and D. 10-16-28 $\mu$. The wood parenchyma is formed of some -what rectangular, axially elongated cells with lignified pitted walls. They measure about L. 6-10-12 $\mu$ and $\mathrm{W}$. 3-6-8 $\mu$. The phloem is parenchymatous traversed by sieve tubes, companion cells, tannin idioblasts (stained dark blue with aqueous $\mathrm{FeCl}_{3}$ T.S.) and schizogenous canals, measuring about D. 18-24-47 $\mu$.

Pith: It is narrow and consists of large polygonal or rounded parenchymatous cells showing large intercellular spaces with slightly lignified and pitted walls. It shows occasional tannin idioblasts (stained dark blue with aqueous $\mathrm{FeCl}_{3}$ T.S.).

The rachis: A transverse section (Fig. $4 \mathrm{~A})$ in the rachis is nearly circular in outline. It shows a narrow cortex, a continuous ring of pericyclic fibers and a vascular tissue surrounding central pith attaining about $1 / 3$ of the diameter of the section.

The epidermis (Fig. 4C): It consists of tabular polygonal cells, with straight anticlinal walls covered with striated cuticle. They measure about L. 10-14-18 $\mu$, W. 6-10-12 $\mu$ and $\mathrm{H}$. 7-12-14 $\mu$. 


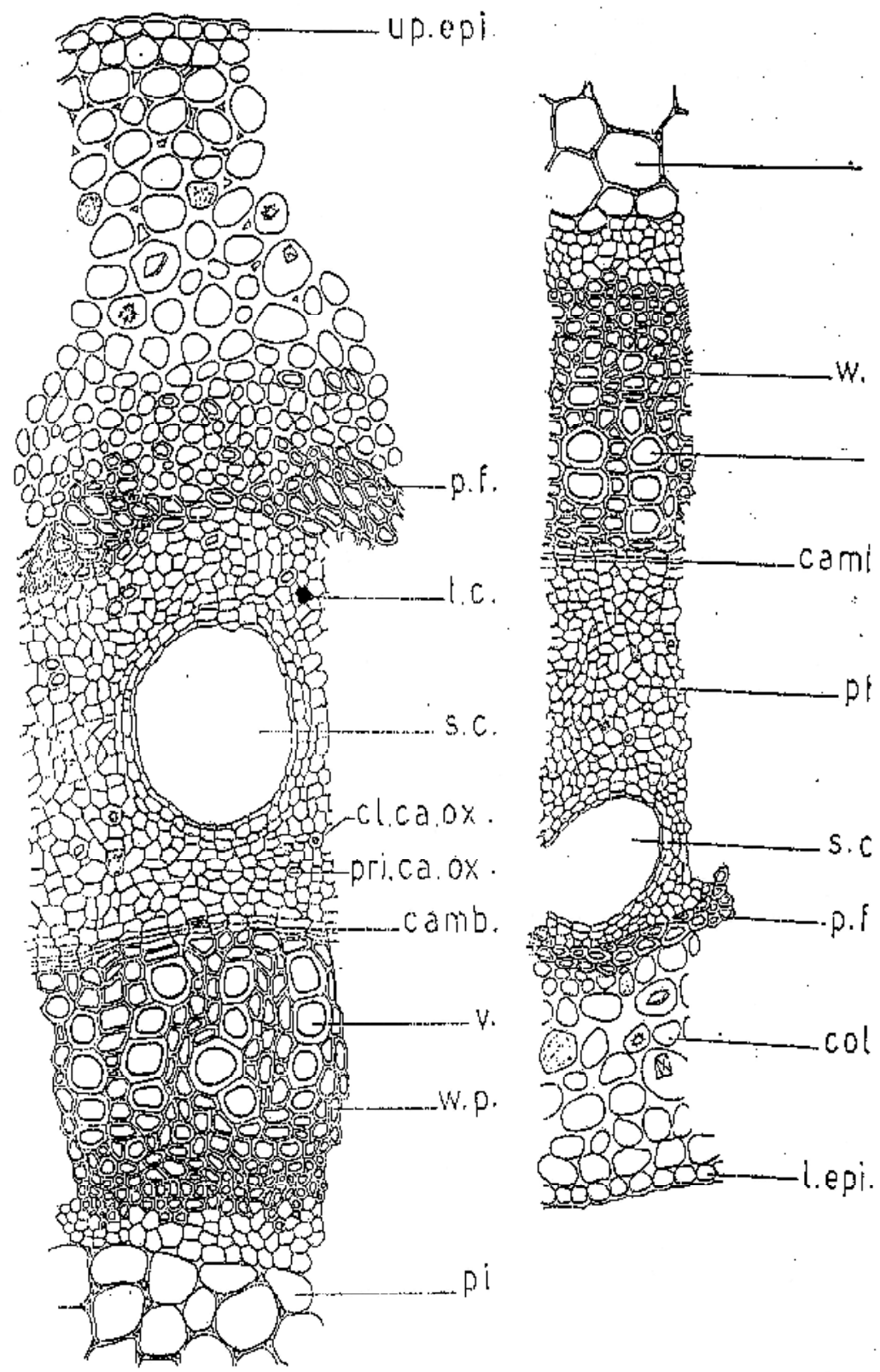

Fig. 3: The leaflet

Detailed transverse section

(X 385)

Camb. Cambium; cl. ca. ox., cluster of calcium oxalate; col., collenchyma; 1. ep., lower epidermis; p.p., pericyclic fibre; ph., phloem; pi., pith; pr. ca. ox., prism of calcium oxalate; s.c., secretory canal; t.c., tannin cell; up. ep., upper epidermis ; v., vessel; w.p., wood parenchyma. 
8

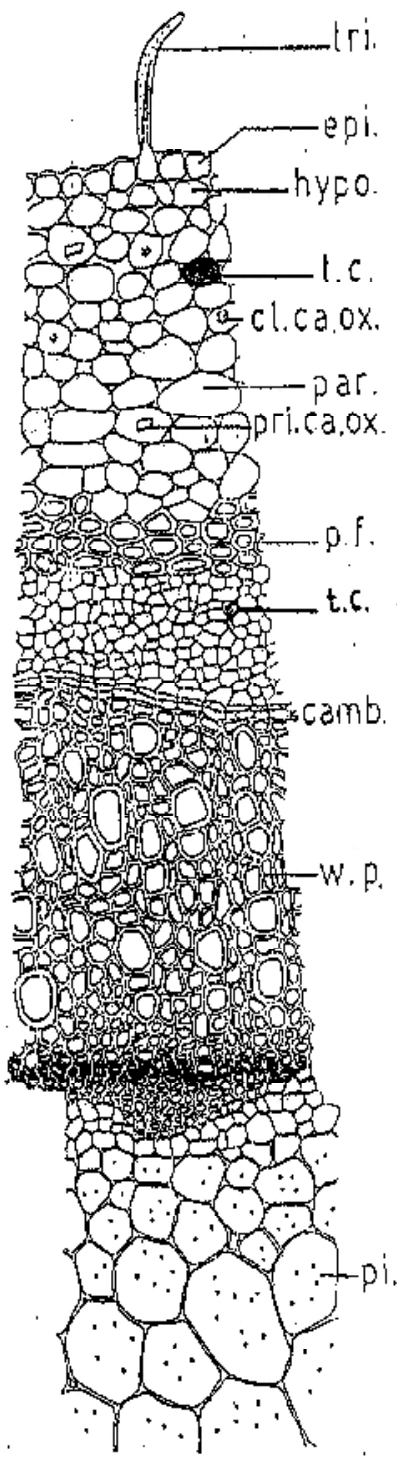

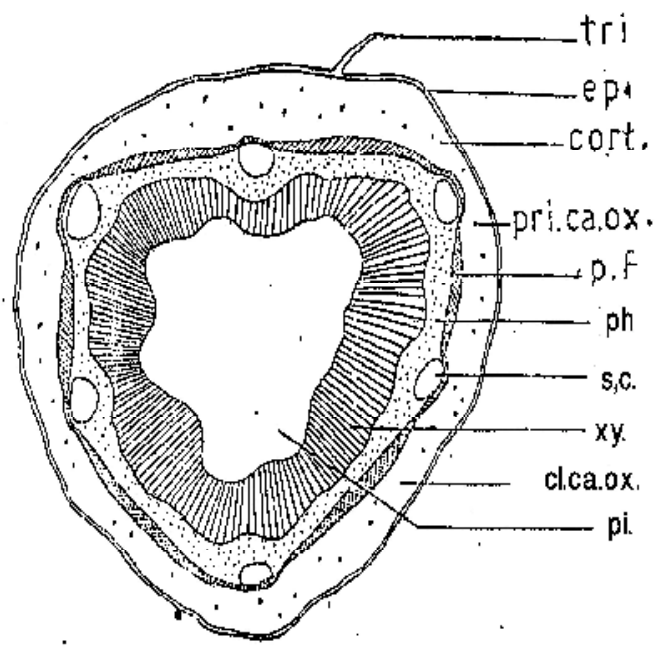

C

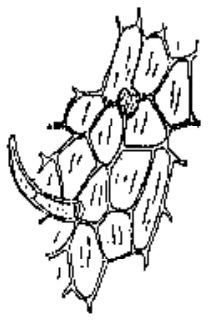

Fig. 4: The rachis of the leaf

A- Diagramatic transverse section

B- Detailed transverse section

(X 250)

C- Surface preparation

(X 290)

camb., cambium; cl. ca. ox., cluster of calcium oxalate; cort., cortex ; ep., epidermis; hyp., hypodermis; par., parenchyma; p.p., pericyclic fibre; Ph., phloem; pi., pith; pr. ca. ox., prism of calcium oxalate; s.c., secretary canani; t.c., tannin cell; w.p., wood parenchyma; xy., xylem. 
Trichomes and stomata are similar to those present on the leaflets. The nonglandular trichomes are scattered all over the surface of the rachis especially on the adaxial side.

The cortex (Fig. 4B): It is formed of parenchymatous cells with narrow intercellular spaces. Occasional prisms of calcium oxalate, measuring L. 3-5-7 $\mu$ and W. 2-3-5 $\mu$, clusters of calcium oxalate measure D. 6-8-10 $\mu$ and scattered idioblasts are observed.

The pericycle (Fig. 4B): It is formed of continuous ring of nonlignified fibers. They have thick walls, narrow lumen, blunt apex and measure $\mathrm{L}$. 500-1200-1400 $\mu$ and D. 8-12-18 $\mu$. The vascular tissue (Fig. 4B) is formed of phloem and xylem surrounding wide pith. The phloem is parenchymatous showing sieve elements, companion cells and occasional tannin idioblast and is traversed in the outermost region by secetory canals, measuring D. 50100-180 $\mu$. The cambium consists of 2-4 rows of merisdmatic cells. The xylem consists of vessels, tracheids, fibers and wood parenchyma and traversed by uni or biseriate medullary rays. The vessels are lignified, annular, pitted and reticulate, measuring D. 12-30-40 $\mu$. The tracheids are lignified, reticulate and elongated measuring L. 40-65-80 $\mu$ and D. 12-20-30 $\mu$. The wood fibres are of occasional occurrence, lignified thick walled with pointed ends and measure L. 100-130-200 $\mu$ and D. 1017-30 $\mu$. The wood parenchyma is lignified, axially elongated with pitted walls, measuring L. 7-9-15 $\mu$ and $\mathrm{W}$. $3-5-8 \mu$. The pith is parenchymatous with, narrow intercellular spaces and slightly lignified pitted walls.

The powdered leaf (Fig. 2F): It is green in colour, with an aromatic black-pepper like odour and slight astringent taste. It is microscopically characterized by the following:

1- Fragments of epidermis of lamina formed of polygonal tabular cells having almost straight or slightly wavy anticlinal walls and distinct striated cuticle with occasional anomocytic sunken stomata on the upper and lower epidermis.

2- Fragments of nonglandular trichomes of the neural region and of rachis. The trichomes are unicellular or uniseriate multicellular 2 to 3 cells, straight or curved, with blunt apices both are covered with warty cuticle.

3- Fragments of palisade cells, some of them contain cluster crystals of calcium oxalate.

4- Prisms of calcium oxalate present in thin walled parenchymatous cells containing prisms of calcium oxalate.

5- Fragments of non lignified pericyclic fibres, having thick walls, narrow lumen and blunt apices.

6- Fragments of lignified wood fibres occassionally present, being thick walled with pointed ends.

7- Fragments of lignified pitted wood parenchyma. 
8- Fragments of collenchymatous cells.

9- Fragments of vascular tissue showing broken annular, spiral and reticulate lignified vessels and few tracheids.

10- Fragments of secretory canals.

The stem: A transverse section (Fig. $5 \mathrm{~A}$ ) of the stem is circular in outline and shows an epidermis (young stem) or cork tissue (in old stem) surrounding a moderately wide primary parenchymatous cortex. The pericycle is formed of continuous ring of fibres. The phloem is traversed by secretion canals. The xylem is wide (equal to bark in width) and surrounds a wide parenchymatous pith, attaining $1 / 2$ diameter of the section, the vascular tissue is radially traversed by numerous narrow medullary rays.

The epidermis (Fig. 5C\&D): It consists of tabular polygonal cells, isodiametric or elongated cells and have straight or slightly wavy anticlinal walls. These cells are covered with striated cuticle and measure L. 8-14-21 $\mu$, W. 5-13-16 $\mu$ and $\mathrm{H}$. 7-11-15 $\mu$. Stomata are occasional; oval sometimes rounded in shape an sunken. They are usually of anomocytic type and measure $\mathrm{L}$. 19-24-30 $\mu$ and W. 14-23-27 $\mu$.

Trichomes: They are of non glandular type are unicellular and uniseriate multicellular. The unicellular hairs are conical $\mathrm{m}$ shape, with blunt apices and measure about L. $15-90-20 \mu$ and W. $10-12-18 \mu$ at the widest part at the base. The multicellular hairs are uniseriate of 3 to 5 cells, straight or curved, having blunt apices and measure L. 20-100$230 \mu$ and W. 10-14-20 $\mu$. Both types of trichomes are covered with smooth or warty cuticle.

The old stem (Fig. 5B): Phellogen is formed in the outer region of the cortex. It gives to the outside radial rows of tangentially elongated brown cork cells with suberised walls followed by 3 to 4 rows of thin walled parenchymatous cells of phelloderm (secondary cortex). The cork cells measure L. 10-12-30 $\mu, \mathrm{W}$. 14-18-30 $\mu$ and H. 8-13-17 $\mu$.

The cortex (Fig. 5B): It is formed of rounded parenchymatous cells with narrow intercellular spaces and occasional prismatic L. 3-5-8 $\mu$ and W. 2-3-5 $\mu$ and cluster crystals of calcium oxalate D. 7-9-12 $\mu$. Idioblasts of tannin cells are scattered in the cortex. The cortical cells measure L. 20 25-31 $\mu$ and W. 18-25$27 \mu$.

The pericycle (Fig. 5B): It is formed of a complete ring of lignified, thick walled fibres with irregularly narrow lumen and blunt apices. Some fibres are thin walled with wide lumen. The fibres measure L. 900-1900-2500 $\mu$ and W. 6-9-16 $\mu$.

The vascular tissue (Fig. 5B): It is formed of phloem to the outline and xylem to the inside. These are separated by $2-5$ rows of thin walled 
$B$

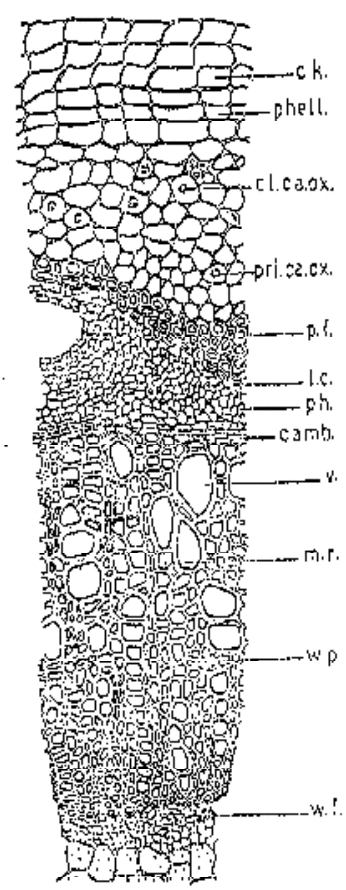

C

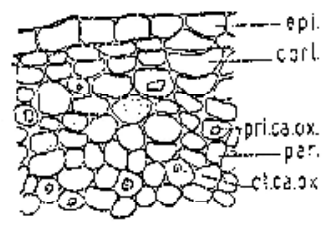

A

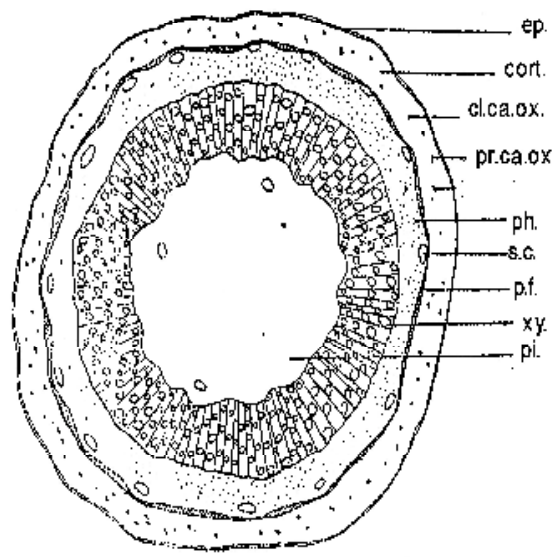

D

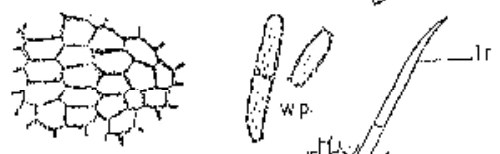

$$
\text { ch. }
$$

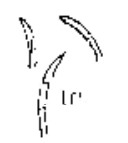

piper.

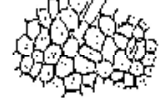

is a cor

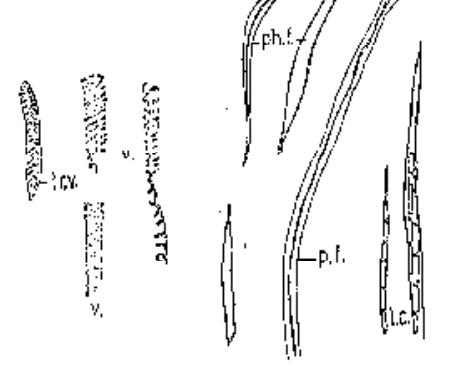

Fig. 5: The stem

A- Diagramatic transverse section of the stem

B- Detailed transverse section

C- Epidermis and cortex of young stem

D-Powder

camb., cambium; cl. ca. ox., cluster of calcium oxalate, ck., cork; cort., cortex; ep., epodermis; par., parenchyma; p.f., pericydic fibre; ph., phloem; ph.f., phloem fibre; phell., phelloderm., pi., pith; pi.par., pith parenchyma; pr. ca. ox., prism of calcium oxalate; s.c., secretory canal; scl., sclereid; t.c., tannin cell; tr. v., trancheidal vessel; tr., trichome; v., vessel; w.f., wood fibre; w.p. wood parenchyma; xy., xylem. 
tangentially elongated cambium cells interrupted by numerous uniseriate occasionally biseriate radially elongated cells of medullary rays. The phloem is represented by thin walled parenchymatous cells, sieve tubes and companion cells and is traversed by large secretory ducts, arranged in a concentric ring, measuring D. 40-90$160 \mu$. Tannin idioblasts and cluster crystals of calcium oxalate are scattered through the phloem, measuring D. 5-7-9 $\mu$.

The xylem: It is formed of lignified elements of vessels tracheids, wood fibres and wood parenchyma and traversed by uniseriate, radially biseriate medullary rays. The primary xylem consists of lignified, spiral, annular and reticulate vessels. The secondary xylem consists of pitted and reticulate vessels which are scattered solitary or in groups of 2 to 5 occasionally up to 7 vessels. They measure D. 16-42-80 $\mu$. The tracheids are pitted, reticulate and lignified, measuring L. 100-150-200 $\mu$ and D. 12-22-30 $\mu$. The wood fibres are of occasional occurrence. They are lignified, thin or thick walled with pointed ends and measure L. 170200-250 $\mu$ and D. 13-25-35 $\mu$. The wood parenchymatous are lignified, axially elongated with pitted walls, measuring L. 5-8-12 $\mu$ and W. 3-5-8 $\mu$ and occasional pitted and lignified sclereids measuring about L. 12-13$14 \mu$ and W. 5-6-7 $\mu$.

The pith: It consists of slightly lignified large, polygonal or rounded parenchymatous cells with narrow intercellular spaces.

The powdered stem (Fig. 5D): It is yellowish-green in colour with an aromatic black-pepper like odour and astringent characteristic taste. Microscopically, it is characterized by the following:

1- Fragment of epidermal cells which are polygonal, nearly isodiametric with straight or slightly wavy anticlinal walls, covered with thin striated cuticle, showing occastional anomocytic stomata and non glandular trichomes.

2- Non glandular trichomes of unicellular and multicellular uniseriate type, straight or curved. Both are covered with smooth or warty cuticle.

3- Fragments of thin walled phloem parenchyma containing clusters of calcium oxalate and showing numerous scattered tannin idioblasts.

4- Fragments of wood fibres with lignified, thick walled and tapering pointed tips.

5- Fragments of lignified pericyclic fibres, with more or less thick or thin walls and blunt apices.

6- Fragments of spiral, annular, pitted and reticulate vessels accompanied by tracheids and wood fibres.

7- Fragments of lignified pitted wood parenchyma traversed by medullary rays cells.

8- Fragments of rounded or polygonal parenchymatous cells 
of pith, with slightly lignified pitted walls.

9- Fragments of parenchymatous cells of the cortex -with tannin idioblasts and prisms and clusters of calcium oxalate.

10- Fragments of secretory canals associated with phloem parenchyma cells.

11- Fragments of brown polygonal cork cells of old stem having suberized walls.

\section{REFERENCES}

1- B. L. B. Edith, C. Carlos and Y. Yoskiko, Fed. Parana University Press, Argent. Cience cult. Soapoulo, 7, 613 (1973) through C. A., 80, 6874 (1974).

2- C. R.Metcalf and L. Chalk, "Anatomy of the Dicotyledons", Vol. 1 Clarendon Press, Oxford, 1972, p. 450.

3- G. A. EI-Hossary, "Pharmacognostical Study of Certain Saponaria and Valeriana Species Grown in Egypt", Ph.D. Pharm. Sci. Thesis, Cairo University, 1970, pp. 2, 132.

4- The Dispensatory of the United States of America, 25 ${ }^{\text {th }}$ Ed. J.B. Lippinrott Co., Philadelphia, Montreal, 1960, p. 1837.

5- M. Gomzalz, J. Anales Facultad. Quin. Farm, University Montevides, 1, 133 (1931).

6- M.R. de Lima, J. de Souza Luna, A. F. dos Santos, M. C. de Andrade, A. E. Sant'Ana, J. P. Genet, B. Marquez, L. Neuville and N. Moreau, J.
Ethnopharmacol., 21, 105, 137 (2006).

7- L.C. Queires, F. Fauvel-Lafetve, S. Terry, A. De la Taille, J. C. Kouyoumdjian, D. K. Chopin, F. Vacherot, L. E. Rodrigues and M. Crepin, Anticancer Res., 26, 379 (2006)

8- T. Hayashi, K. Nagayama, M. Arisawa, M. Shhnizu, S. Suzuki, M. Yoshizaki, N. Morita, E. Ferro, I. Basualdo and L. H. Berganza, J. Nat. Prod., 52, 210 (1989).

9- M. S. Karawya, M. S. Afifi, A. F. Halim and S. H. El-Sharkawy, Bull. Fac. Pharm. Cairo Univ., 27, 3 (1989).

10- M. S. Karawya, M. S. Afifi, A. F. Halim, M. S. Hifnawy and M. S. El-Sharkawy, ibid., 3 (1989).

11- L. H. Baily, "Manual of Cultivated Plants", $4^{\text {th }}$ Ed., MacMillan Co., New York, 1958, p. 625.

12- A. F. Hill, "Economic Botany", $2^{\text {nd }}$ Ed., Mcgraw-Hill Book Co, INC- New York, Toronto, 1952, p. 153 .

13- L. Benson, "Plant Classification", $2^{\text {nd }}$ Ed., D.C. Heath Company, Boston, 1957, p. 176.

14- C. D. Subhash, "A Hand Book of Systematic Botany", $2^{\text {nd }}$ Ed., Indian Reprint, IBH Publishing Co., Calcutta, 1970, p. 132.

15- B. S. Trivedi and B. B. Sharm, "Introductory Taxonomy of Angiosperm", Lucknow University Press, Lucknow, 1970, p. 175 . 
16- A. B. Rendle, "The Classification of Flowering Plants", Vol. II, University Press, Cambridge, 1969, p. 295.

17- J. W. Purseglov, "Tropical Crops of Diccotyledons", Vol. I, MacMillan Co., New York, 1977, p. 18.
18- F. M. Hashim, G. A. EI-Hossary and F. S. El- Sakhaway, J. Afric Med. Plants, 1, 31 (1977). 